\title{
Are Differential Behavioral Responses to Smoking and Smoking Cessation in Schizophrenia Related to Nicotinic Receptor Levels?
}

George et al. (2002) present interesting findings showing a decrease in visuospatial working memory (VSWM) on smoking cessation in schizophrenia, but an increase in VSWM on smoking cessation in non-schizophrenic controls. Divergent responses to nicotine have also been found in gating of $\mathrm{P} 50$ auditory evoked potentials (Adler et al. 1992) and response of eye tracking measures (Olincy et al. 1998). A possible explanation for these disparate results may be variation in expression of nicotinic acetylcholine receptor populations in patient populations and in regulation of this receptor gene family by nicotine.

The neuronal nicotinic receptor gene family consists of two general categories: (1) receptors that bind nicotine with high affinity, principally $\alpha 4 \beta 2$; and (2) receptors that bind nicotine with low affinity, principally $\alpha 7$ (Leonard and Bertrand 2001). In postmortem brain of smokers with no history of mental illness, high affinity nicotinic receptors increase in number and have returned to baseline levels by one to two months after smoking cessation. Further, the number of receptors is correlated with the number of cigarettes smoked per day (Breese et al. 1997). Low affinity $\alpha 7$ receptors may only be increased in very heavy smokers. Receptor regulation by nicotine appears to be identical in peripheral blood cells (Benhammou et al. 2000). Both high and low affinity receptor levels are decreased in postmortem brain of schizophrenics (Freedman et al. 1995; Breese et al. 2000; Leonard et al. 2001) and high affinity receptors are also decreased in peripheral blood cells of schizophrenics (manuscript in preparation). At every smoking level, schizophrenics have fewer nicotinic receptors than controls with no history of mental illness.

How might these findings explain a diverse response to nicotine and smoking cessation in schizophrenics and controls? Nicotinic receptors rapidly desensitize after nicotine exposure and resensitization is slower than desensitization (Grady et al. 1994; Marks et al. 1994). Repetitive nicotine intake leads to the accumulation of a subset of receptors that have a blunted response to nicotine, but increase in number due to an increased half-life (Peng et al. 1994; Dani and Heinemann 1996). On smoking cessation, the receptor population resensitizes and, until turnover, is available to the endogenous ligand, acetylcholine. In abstinent control smokers, at one-week post cessation, an increased response to acetylcholine may occur due to both the increased number of receptors and their resensitization. The non-abstinent control smokers have an increased number of receptors, but their receptors are still desensitized. This biological difference translates into improvement in cognitive tasks in the abstinent control smokers. In the schizophrenic group, there is a lower number of receptors in the smoking group and exogenous nicotine is, presumably, required to support VSWM. On abstinence, acetylcholine has fewer receptors to activate, as they were not increased to the extent seen in controls, and there is, thus, a worsening of VSWM.

While this is only one of many possible explanations for discrepant responses on working memory tasks after smoking cessation, e.g. different neuroadaptive responses, it represents an attempt to relate a known biological difference in nicotinic receptors to behavioral measures.

Sherry Leonard, Ph.D., and Laura Giordano, M.D. Department of Psychiatry, University of Colorado Health Sciences Center 


\section{REFERENCES}

Adler LE, Hoffer LJ, Griffith J, Waldo MC, Freedman R (1992): Normalization by nicotine of deficient auditory sensory gating in the relatives of schizophrenics. Biol Psychiatry 32:607-616

Benhammou K, Lee MJ, Strook M, Sullivan B, Logel J, Raschen K, Gotti C, Leonard S (2000): $\left[{ }^{3} \mathrm{H}\right]$ Nicotine binding in peripheral blood cells of smokers is correlated with the number of cigarettes smoked per day. Neuropharmacology 39:2818-2829

Breese CR, Lee MJ, Adams CE, Sullivan B, Logel J, Gillen KM, Marks MJ, Collins AC, Leonard S (2000): Abnormal regulation of high affinity nicotinic receptors in subjects with schizophrenia. Neuropsychopharmacology 23:351-364

Breese CR, Marks MJ, Logel J, Adams CE, Sullivan B, Collins AC, Leonard S (1997): Effect of smoking history on $\left[{ }^{3} \mathrm{H}\right]$ nicotine binding in human postmortem brain. J Pharmacol Exp Ther 282:7-13

Dani JA, Heinemann S (1996): Molecular and cellular aspects of nicotine abuse. Neuron 16:905-908

Freedman R, Hall M, Adler LE, Leonard S (1995): Evidence in postmortem brain tissue for decreased numbers of hippocampal nicotinic receptors in schizophrenia. Biol Psychiatry 38:22-33

George TP, Vessicchio JC, Termine A, Sahady DM, Head
CA, Pepper WT, Kosten TR, Wexler BE (2002): Effects of smoking abstinence on visuospatial working memory function in schizophrenia. Neuropsychopharmacology 26:75-85

Grady SR, Marks MJ, Collins AC (1994): Desensitization of nicotine-stimulated $\left[{ }^{3} \mathrm{H}\right]$ dopamine release from mouse striatal synaptosomes. J Neurochem 62:1390-1398

Leonard S, Adler LE, Benhammou K, Berger R, Breese CR, Drebing C, Gault J, Lee MJ, Logel J, Olincy A, Ross RG, Stevens K, Sullivan B, Vianzon R, Vernich DE, Waldo M, Walton K, Freedman R (2001): Smoking and mental illness. Pharmacol Biochem Behav 70:561-570

Leonard S, Bertrand D (2001): Neuronal nicotinic receptors: from structure to function. Nicotine Tobacco Res 3:203-223

Marks MJ, Grady SR, Yang JM, Lippiello PM, Collins AC (1994): Desensitization of nicotine-stimulated ${ }^{86} \mathrm{Rb}^{+}$efflux from mouse brain synaptosomes. J Neurochem 63:2125-2135

Olincy A, Ross RG, Young DA, Roath M, Freedman R (1998): Improvement in smooth pursuit eye movements after cigarette smoking in schizophrenic patients. Neuropsychopharmacology 18:175-185

Peng X, Gerzanich V, Anand R, Whiting PJ, Lindstrom J (1994): Nicotine-induced increase in neuronal nicotinic receptors results from a decrease in the rate of receptor turnover. Molec Pharmacol 46:523-530 